\title{
FOOD TOURISM IN THE CZECH REGIONS \\ - TRENDS AND OPPORTUNITIES
}

\author{
Iveta Hamarneh, Alžbeta Királ’ová
}

\begin{abstract}
Tourism is a significant part of the contemporary experience economy, in which food plays an important role. Food is a fundamental part of all cultures, and one of elements of creativity in everyday life that is engaging for many visitors. Food is also an element that is easily linked to the tourism industry and contributes to the economic development and improvement of national image. This provides new opportunities for tourism destination and at the same time creates new challenges. The overarching aim of the paper is to introduce and evaluate regional and local food and beverages as a viable factor for future tourism development in the Czech regions. Methods which were used for completing the paper included the literature review, content analysis of documents and in-depth interviews.
\end{abstract}

Keywords: food tourism, local and regional food, regional development, trends in food tourism

\section{Introduction}

Food is an important part of the tourism product. No matter if they want to or not, or where and when they are traveling, people have to eat. It should, therefore, be no surprise that „more of the tourist dollar is spent on food and beverage than any other service“" (Mill, Morrison, 1998, p. 190). This suggests that food in tourism has great potential to generate income for both producers and providers of food. Furthermore, food preparation and service contribute substantially to tourism employment because of it is often relatively labor intensive (Selwood, 2003).

Tourism-related food production is therefore potentially a significant mechanism for economic development. However, on the potential contribution of food to regional development, a critical issue is whether food production and preparation that visitors consume occur locally or not. As Bèlisle (1983) noted over 20 years ago, „As food accounts for approximately one-third of tourist expenditure, the proportion of food imports for tourist consumption can affect significantly the economic and social impact of tourism“ (p. 498). Nevertheless, the potential benefits of food and tourism relationship for regional development are not just isolated to consumption. In certain types of special interest tourism, food becomes a central motivation for travel (Hall, Mitchell, 2001). Indeed, Hashimoto and Telfer (2003) note how food in tourism has developed from being a necessity to 
become an additional „tourist experience“ that may enhance the overall evaluation of the travel experience. The maximization of economic linkages between local producers and providers and tourists is therefore of great importance in the promotion of local and regional food and therefore maximizing the potential contribution of tourism to regional development (Hall, 2004, Telfer, Wall, 1996).

The regional distribution of tourism flows in the Czech Republic is problematic. The most visited area is Prague, Karlovy Vary Region, South Moravian Region, Central Bohemian Region, South Bohemian Region and Hradec Králové Region. Food tourism can be a means for the better economic development of the regions with high unemployment and low socio-economic status. The future growth of the food tourism can be supported by the existing conditions for it (attractive location, agriculture land, production of hops and vegetables, growing grapes, rural areas, etc.) (Hamarneh, Királ’ová, 2016a).

The overarching aim of the paper is to introduce and evaluate regional and local food and beverages as a viable factor for future tourism development in the Czech regions.

\section{Methodology}

According to the objective of the paper, the research question was formulated as "Can the interest in food tourism support the future tourism development in the Czech regions with low tourist flows?". Czech regions combine some prerequisites for food tourism development with a long lasting tradition of preparation food culture.

The analysis and data presented in this article are based on primary and secondary research. Secondary research includes the literature review and content analysis of documents. A literature review was mainly applied in exploring the relationship of food tourism and regional development, the definition of local and regional food and beverages and the introduction of current trends in food tourism. Content analysis of documents was mainly used in exploring the prerequisites for food tourism in the Czechia.

Primary qualitative research, using an inductive method, was applied to this study as it is suitable for use with a small sample. An interview approach (in-depth interviews) was used to understand the meanings that respondents appended to issues in more depth, rather than just describe them at a superficial level as can be reached by the use of questionnaires (Breakwell et al., 2000, Eves, Dervisi, 2005). The research included face-to-face interviews in a one-to-one setting with the stakeholders. The specific selection criteria for the purposeful sampling as (1) duration of the restaurant minimum one year, (2) restaurant with the Czech cuisine, (3) and holding a manager role were determinate. The entire sample was selected by snowball sampling method, by the quality of web pages and also by the observation in the restaurants. 
In a semi-structured interview (Murphy, 1988, Merriam, 2009), the interviewees were asked to express personal opinions and display their expertise. The outline of questions was prepared and formulated with the help of Patton's (2002) six types of interview questions. The interviews were recorded on tape with permission of interviewees afterward analyzed through transcription and deidentified. For each interview, a summary was prepared. Content analysis and standard, systematic, qualitative coding techniques were applied. Given the qualitative nature of the information gathered and the size of the sample, the survey responses were not amenable to statistical analysis.

The current study initially recruited 30 participants (seventeen of the respondents were from Prague and thirteen from Central Bohemian Region) for individual in-depth semi-structured pilot interviews in a period of three months from December 2015 to February 2016. The pilot interviews ranged in duration between 30 and 60 minutes and aimed to identify key themes and issues relating to how participants perceive the importance of local food / beverages in their business, and these lead to the development of an interview guide for the primary phase of the data collection.

Considering confidence $99 \%$ and margin of error 5\% the sample was estimated on approximately 580 respondents. This is based on Krejcie and Morgan (1970). The number of interviewees has been set by the number of gastronomic establishments (41 160), by the number of facilities with the Czech cuisine (28\%) and by the number of restaurants from the total amount $(37,1 \%)$. Depending on the quality of web pages and observation in the restaurants we process a selection of the typical ones. The resulting number of interviews was 281 .

The research included face-to-face interviews in a one-to-one setting with two hundred and eighty-one tourism stakeholders (see table 1). At this stage, the purpose and the subject of the interview were outlined. Given the qualitative nature of the information gathered and the size of the sample, the survey responses were not amenable to statistical analysis.

Our qualitative research is focused on the small and medium-sized enterprises operated in hospitality services. Unfortunately, the most of the current research is aimed at analyses consumers' and visitors' opinions and motivations in connection to the food-related experiences. Here we can see the benefits of our paper.

\section{Food Tourism and Regional Development}

Travel motivated by food is referred to food tourism, culinary tourism, cuisine tourism, gourmet tourism, gustatory tourism, food and wine tourism, food and beverage tourism, rural tourism, cuisine travel, urban tourism, gastronomic tourism and taste tourism. The most common name is gastronomic tourism, culinary tourism, and food tourism. (Hamarneh, Királová, 2016b). 
Food tourism includes visits to destinations which are motivated principally by an interest in native national or regional gastronomy and can include sampling food and beverages, learning about production processes, buying food- or drinkrelated products, or attending cookery courses (Macleod, Robertson, Smith, 2010).

Food tourism is in a focus of today's visitors' itinerary and a part of the tourism destinations' strategies. The interest of visitors in food tourism is growing together with interest in culture, traditions, emotions, experiences and creativity. In his study, Yeoman (2016) identifies the key drivers of food tourism development as follows:

- Food tourism as a political capital;

- Food tourism as a visionary state;

- What it means to be a foodie;

- The drive for affluence and exclusivity;

- Fluid experiences in a post-modernist world.

According to Yeoman (2016), ,food tourism as a collective discourse binds farmer, producer, distributor, retailer and consumer together thus providing stakeholders and communities a utopian vision of the future. Through the creation of visions, political capital is created as political leaders see the opportunity to create dialogue through common purpose i.e. the land, food and the tourist. These are the elements of policy and strategy which focus on the high-value tourist characterized by affluence and exclusivity. To the food tourist, food is their identity. This identity is fluid and is shaped by authenticity and hedonistic experiences".

Food is an important place-marker in tourism promotion. The climatic conditions, culture, and history of a region shape the character of the food that is produced. Gastronomy is often said to be a sub-sector of cultural or heritage tourism for this reason. The link between location and gastronomy has been used in some ways in tourism, including promotional efforts based on distinctive or „typical“ regional or national food. Food can also be used as a means for guiding visitors around regions and countries, for example in the forms of trails (Hjalanger, Richards, 2002).

The impact and benefits of food tourism for region can include an increased demand for food-related products, the building of brand loyalty, marketing intelligence for producers and suppliers, educational opportunities for visitors and residents, regional and local employment creation, extension of the tourists'stay in an area, wider distribution of spending, and the protection of intellectual property (Macleod, Robertson, Smith, 2010, Hashimoto, Telfer, 2003, Misiura, 2006).

\section{Local and Regional Food}

The Enteleca Research and Consultancy report (2000) on tourists' attitudes towards regional and local food in the UK state that there is no single universally 
agreed or adopted the definition of local food and beverages. Consumers make little distinction between „local produce“ and „local specialties“ (Hall, Sharples, Smith, 2003), a situation that is further confused by the increasing global availability of „regional“ products (Inteleca Research Consultancy, 2000). Enteleca adopted the definition of local food as ,food and drink that is produced or grown in the local area or local specialty food that has a local identity" and that includes fresh ,farm gate' sales, regionally branded and locally produced products, and local specialty products, that are in some way distinctive to the area or unique" (p. 11). In other words, this definition indicates that local food is not only about locally grown produce but should also include food and requires raw material from outside the area, but that is processed locally and thereby given a local or regional identity.

The growing interest and demand from tourists for local fare is very much rooted in the changing patterns of tourism, particularly the growth of „special interest" (Hall, Mitchell, 2001) and "new" tourism (Poon, 1993). According to Poon (1993), new tourists are searching more for real and authentic cultural and natural experiences. As food has been recognized as an important part of local culture and identity (Richards, 2002), trying out local food specialties may serve to enrich the overall experience of tourists seeking to learn more about a different and authentic culture.

Enteleca survey showed that many visitors have to be exposed to local foods to take an interest in them, and therefore it will be of great importance that food producers, eating establishments, and other involved stakeholders actively promote and visualize local food produce.

\section{Trends in Food Tourism}

"Today, the customer is better educated, wealthy, has traveled more extensively, lives longer, and is concerned about his health and the environment. As a result, food and drink have become more important and have a higher priority amongst certain social groupings. To the extent, food is the new culture capital of a destination, as if the culture has moved out of the museum to become a living experience of consumption" (Yeoman, 2008). The trends that enhance visitors' interest in food tourism were defined by Yeoman (2008) as follows:

- Disposable Income and Spending Patterns;

- Demographics and Household Change;

- Individualism;

- The Multi-Cultured Consumer;

- The Role of the Celebrity Chef and Media;

- Well-Being and Food;

- Food as an Oasis;

- Internet Usage;

- The Desire for New Experiences and Cultural Capital; 
- The Science of Food;

- However, the Consumer is a Hypochondriac.

Gastronomy doesn't specifically relate to the method by which food and beverage are produced, material component of food and drinks or even meal or cooking, but alternatively, it covers the wider scope beyond simply what we eat and in what form to also involve how we eat (hand, fork or chopstick), where we eat (on the floor, at the table, seated or standing) when we eat, why we eat, with whom we eat (family or social networks).

Successful destinations have begun to realize that there is a great potential for food tourism to offer a sustainable tourism product and they use food as a means to create cultural capital and social cachet. Creating a network of food and drink suppliers and offering an eating and shopping experience for visitors in authentic local promises based upon high quality and unique product that is fair priced are the prerequisite for satisfied visitors. This cannot be achieved without the involvement of all stakeholders.

\section{Prerequisites for Food Tourism in the Czech Regions}

Every year, the Czech Republic welcomes over 8 million domestic and 25 million international visitors. (Ministry of Regional Development, 2016). Tourism plays a vital role in Czech Republic's economy, accounting for close to 3 percent of Czech Republic's gross domestic product, close to 5 percent of Czech Republic's employment and representing almost 25 percent of total service exports in 2014 (CSO, 2016). But the regional distribution of tourism flows in the Czech Republic is problematic. In 2015, the most visited region by foreign tourists was Prague, followed by the Karlovy Vary region, and South Moravian Region. If we take into account domestic visitors (long-term stays), the most visited are Central Bohemian Region, followed by the South Bohemian Region and Hradec Králové Region (Hamarneh, Kočová, 2016).

In an international comparison, the Czechia is a country with a higher than the average proportion of arable land about its total area and a marginally above the average percentage of forested land, although only about half the value found in Scandinavian countries. Regarding growing and other areas, the Czech Republic is rather below the average, particularly in comparison with Germany, France, and Italy, where the percentage of growing and other areas is high (Ministry of Agriculture of the Czech Republic, 2013). Along with the connected food production industry, agricultural production is one of the major traditional divisions of the Czech economy. In the area of crop production, the principal activity is the cultivation of cereals and oilseeds. Legumes, sugar beet, potatoes, hops, vegetables, fruit, and vines are also cultivated in the Czech Republic. The Czechia is the fourth largest producer of hops in the world (after Germany, the USA, and China). 
Figure 1: Number of food and beverages facilities by region in 2014

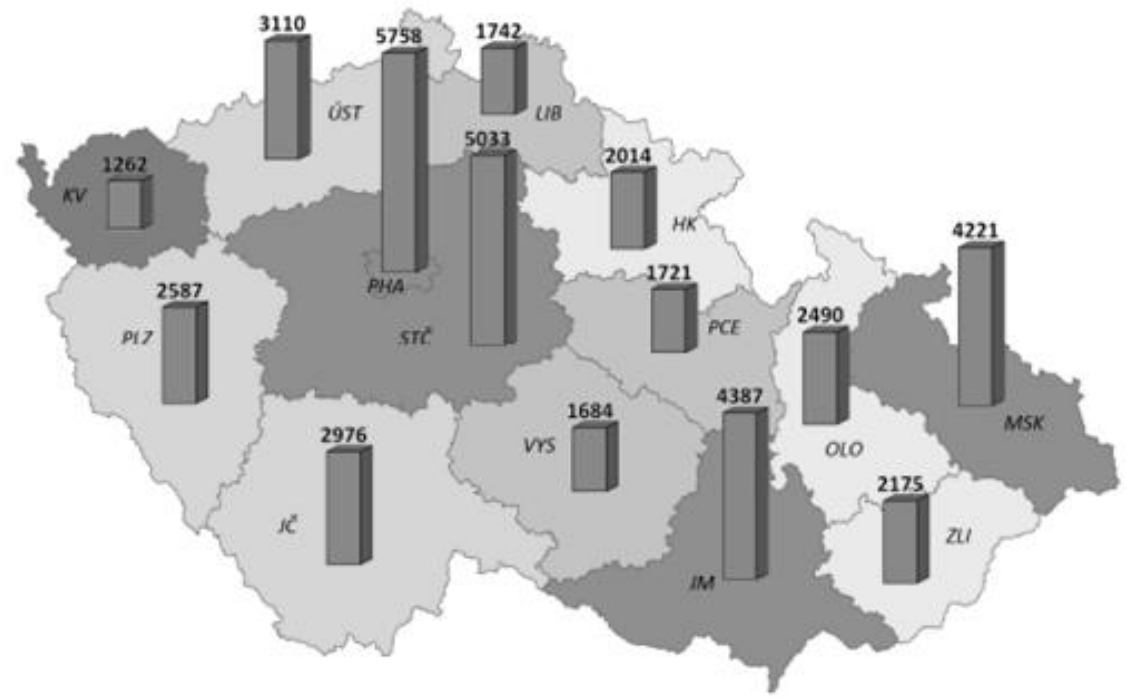

Names of regions:

PHA - Prague

STČ - Central Bohemian Region

JČ - South Bohemian Region

PLZ - Plzeň Region

KV - Karlovy Vary Region

ÚST - Ústí nad Labem Region

LIB - Liberec Region

HK - Hradec Králové Region

PCE - Pardubice Region

VYS - Vysočina Region

JM - South Moravian Region

OLO - Olomouc Region

ZLI - Zlín Region

MSK - Moravian-Silesian Region

Explanations of colors:

$14-10,3 \%$ of the total

$7,6-6,3 \%$ of the total

$6-4,9$ of the total

$4,9 \%$ of the total

$4,2-4,1$ of the total

Source: Ministry of Regional Development, 2015 
In the Czechia, we currently register a total of 41160 gastronomic facilities. From a regional perspective, the gastronomic facilities are distributed unevenly. As figure 1 shows, the dominant position has Prague, Central Bohemian Region, South Moravian Region and Moravian-Silesian Region. The highest price level we register in Prague, while the lowest price level is in the Ústí nad Labem Region and Vysočina Region (Ministry of Regional Development, 2015).

Food festivals, farmers' markets, and other events, such as Wine Harvest, Christmas markets, Eastern markets, which offer a delicious assortment of food, beverages, and quality organic products, are growing in popularity. These events operate in different parts of the Czechia, including the most of the Czech regions. It is interesting that in the Czech Republic every year, increasing the number of municipalities that boast a local brewery. Municipalities are no longer just their historical and cultural sights, but also its good beer.

Czech cuisine has progressed over hundreds of years and has been determined by Austrian and Hungarian cuisines, yet it has also influenced the cuisines of its bordering nations in return. Czech national cuisine is based on ingredients that can be grown domestically, i.e. potatoes, leguminous plants, and cereals, which are usually served with beef, pork or poultry, or, in some areas, with freshwater fish. These naturally common ingredients have been used to create attractively and original dishes that you can indeed only find in Czech cuisine.

It is worth mentioning some unique dishes that are typical for the regions of the Czechia. For example, the city of Olomouc in Moravia has become famous for its local soft ripened cheeses. In the area of Pardubice, you can try delicious gingerbread. Unique cakes are baked in the area of Chodsko; South Bohemia is typical for dishes with freshwater fish, Prague has become famous for its ham, and Moravian-Silesian Region is known for „Štramberské uši“ - sweet with an interesting legend of cutting of ears during Turkish incursions in the area.

Brewing has been a traditional activity in the Czech Republic for centuries. This is confirmation by one of the oldest breweries in Bohemia, the Regent brewery, which was founded in 1379 by the Rosenberks. To date, this brewery has kept to the traditional method of brewing. The best known Czech breweries include Plzeňský Prazdroj, Budějovický Budvar, Zámecky pivovar in Dětenice, Krušovice and a smaller private brewery, Bernard. It is interesting to note that there are more than 60 breweries in the Czech Republic. Currently, the trend is that breweries, esp. the microbreweries, set up their restaurant which served all his beer.

In the Czechia, grapevines grow best in South Moravia. This is the area where the country's first vineyards were established, around the year 300 A.D. In the 13th century, the Czech aristocracy tried to fertilize barren fields. Most towns in North Bohemia had sloping land lots, which were, in combination with the local climatic conditions, suitable for growing grapevines. The wine trade boomed in this period, being much more profitable than the cereal trade. Viniculture, therefore, gained much in general popularity. 
For small and medium farmers, producers and growers predominantly from the region, there is frequently an almost insuperable problem of getting their products to the formal distribution network of the major retail chains. The method of finding customers while avoiding hypermarkets are supermarkets and private bio-stores. The demand for them is rising because Czech and also foreign consumers are starting to realize how significant it is to have a choice of quality local food, which doesn't use unnecessary preservatives, substitutes, harmful E's and other dangerous chemicals. These shops can be seen in almost every large city in the Czechia.

\section{Results and Discussion}

Table 1: Respondents in interview process

\begin{tabular}{|l|c|}
\hline \multicolumn{1}{|c|}{ Type of enterprises } & Number of interviewees \\
\hline$<10$ (micro enterprises) & 115 \\
\hline$<50$ (small enterprises) & 158 \\
\hline$<250$ (medium-sized enterprises) & 8 \\
\hline
\end{tabular}

Source: Authors

Based on individual in-depth pilot interviews, the interview guide was revised before its use in the main field survey. The finalized interview guide consisted of 18 questions, plus the background information of the respondents (place of business, the number of employees, year of foundation, type of business). Standardized open-ended questions were organized into four sections.

The first section was used to evaluate the extent of what is traditional Czech food (soups, main courses, desserts) successful in the SMEs offer. The questions in the second section were used to find out the extent of the offer of regional food / local drinks and other activities and special menu linked with traditional Czech cuisine. The questions in the third section were used to explore what impact has the offer of regional food / local beverages / special menu in the business:

- on the revenue growth of SMEs;

- on the increase of guests traffic;

- on the image of your entreprise;

- on enhance the average spending of guests.

Information about the ways of support what are used by SMEs in their business was evaluated in the fourth section. We asked the respondents if they actively participate in the events linked with food tourism (such as Food Festivals, Historical markets, Easter and Christmas markets, etc.) and what current trends they apply in their business (for example kitchen open spaces, slow food, hold / participation on food festivals, authentic traditional food offer, the offer of food 
and wine connection, mobile application and wifi connection, sustainable behavior in the operation of gastronomic establishments). Furthermore, this section included the question about concrete tools (financial and non-financial) what are used by SMEs for support of their business. We also asked the respondents if they cooperate with other SMEs in their region.

The interviews took place at the interviewees' workplaces. Gillham (2000, p. 8) points out that "there is a common assumption that people will talk more freely in their environment." The interviews were conducted in each Czech region and took place over a period of four months from March to June 2016.

Based on interviews the following selected trends and findings were identified. Some of the detailed results have been relating to two selected regions the Ústí nad Labem Region and Moravian-Silesian Region. Both Regions belong among less visited, but on the other hand, they offer a sufficient number of gastronomic facilities and these Regions also have other prerequisites for food tourism (Hamarneh, Királ'ová, 2016a, Čuka, Václavínková, 2014, Ministry of Regional Development, 2015).

Soup plays an important role in Czech cuisine. Traditional Czech soups commonly found in Czech restaurants are beef or chicken broth with noodles, optionally served with liver dumplings; garlic, cabbage, goulash or tripe soup. Other typical Czech soups are potato soup, kulajda (traditional South Bohemian soup containing water, cream, spices, mushrooms, egg, dill and potatoes) and kyselo (traditional Northern Bohemian soup made from rye sourdough, mushrooms, caraway and fried onion. The most of the respondents confirmed that traditional Czech soups are very popular among their guests. The very successful soups among customers are chicken and beef broth with noodles and liver dumplings and garlic soup.

Traditional main courses are usually meat-based meals. They often consist of a sauce prepared from cream, which is very thick and nourishing. The traditional side dishes are Czech dumplings (bread dumplings, leavened dumplings and potato dumplings) and any variety of potatoes. The majority of interviewees said that visitors prefer schnitzel with potato salad, roasted duck with sauerkraut and dumplings, and roasted pork with sauerkraut and dumplings. Among less favorite meals belong sweet food - ducat buns and fruit dumplings.

Local drinks are very often integral part of the offer of SMEs. Among the mostly offered local drinks belong beer, spirits, and wine. As the Czech Republic has a strong beer culture, beer belongs among beverages that the gastronomic establishments have included in their offer in greater extent. Presented results in table 2 correspond to the reality that Region is known for its production of hops and fruits (including apples). And recently, the area around city of Most has become a known wine-growing region, in which wine is produced mainly on lands that were reclaimed after brown coal mining. 
Table 2: To what extent do you have included local drinks in your offer? (in \%), the Ústí nad Labem Region

\begin{tabular}{|l|r|r|r|r|r|}
\hline & Always & Most of the time & Sometimes & \multicolumn{1}{c|}{ Rarely } & \multicolumn{1}{c|}{ Never } \\
\hline Wine & 37 & 16 & 32 & 10 & 5 \\
\hline Beer & 58 & 0 & 32 & 5 & 5 \\
\hline Cider & 21 & 10 & 32 & 21 & 16 \\
\hline Spirits & 21 & 11 & 37 & 21 & 10 \\
\hline Herbal tea & 16 & 21 & 42 & 5 & 16 \\
\hline
\end{tabular}

Source: Authors

Results presented in table 3 also correspond to the situation in MoravianSilesian Region. The fact that the Czech Republic is one of the world's leading beer powers is also evident in the region as 13 breweries are based there. The most famous are Radegast.

Table 3: To what extent do you have included local drinks in your offer? (in \%), the Moravian-Silesian Region

\begin{tabular}{|l|r|r|r|r|r|}
\hline & Always & Most of the time & \multicolumn{1}{|c|}{ Sometimes } & \multicolumn{1}{c|}{ Rarely } & \multicolumn{1}{c|}{ Never } \\
\hline Wine & 31 & 62 & 0 & 0 & 7 \\
\hline Beer & 55 & 31 & 7 & 0 & 7 \\
\hline Cider & 16 & 47 & 7 & 7 & 23 \\
\hline Spirits & 47 & 46 & 0 & 0 & 7 \\
\hline Herbal tea & 54 & 16 & 0 & 7 & 23 \\
\hline
\end{tabular}

Source: Authors

Cooking courses, baking courses, tasting menu, tasting drinks are popular among the guests of gastronomic establishments around the world. In the Czech Republic, we are at the beginning. Only a few of respondents claimed preparation of activities, such as tasting menu or tasting beverages, for visitors linked with traditional Czech cuisine. In the regions' comparison, the most active are establishments in Olomouc Region and Karlovy Vary Region.

Almost $80 \%$ of interviewees confirmed that the introduction of regional food and local drinks are having an important influence on the revenue growth of their businesses; increases the guests traffic and improve the image of the enterprise was reported by more than $70 \%$ interviewees; and $60 \%$ of interviewees reported enhancing the average spending of guests.

Only one-third of interviewees confirmed that they actively participate in the events related to food and beverages. The most favorite are participation on Beer festivals and Christmas markets. It is a pity that participation is too low because food festivals include presentations of new products, innovative foodprocessing methods, links between gastronomic regions and showcasing for 
restaurants, famous chef, and seasonal foods. In this way, they can become an important underpinning for local development.

The most of the stakeholders confirmed that they apply only some of the current gastronomic trends in their business. They use primarily mobile application, wifi connection, and sustainable behavior in the operation of their business, that is very positive regarding the sustainable tourism development. Only $15 \%$ of respondents have used open kitchen spaces.

Only $50 \%$ of respondents cooperate with the other SMEs in their region. They most cooperate with the supplier of ingredients and with accommodation facilities. This also corresponds with the results presented by the Ústí nad Labem Region (65\%, respectively $58 \%$ ) and Moravian-Silesian Region (57\%, respectively, $42 \%$ ). It is important to underline that there is the strong emphasis on creating better relationships with the consumer as well as business to business in food tourism.

\section{Conclusion}

Tourism plays a significant role in regional development. Local gastronomy, regional products, and local drinks are perceived as an important part of the local heritage. We think it is a good idea to help promote tourism in the Czech Republic through regional specialties. Czech cuisine is very particularly influenced by the geographical location of the country. The Czech Republic is a landlocked country with a cooler climate; consequently, its cuisine has always been based on ingredients that could be grown at home, chiefly cereals, legumes, potatoes and meat. Each of the Czech regions offers the variety of traditional food and beverages. Regional food and local beverages can support future development of food tourism, and tourism as well, in the regions what are noted for relatively high unemployment, low socio-economic status and low visitation.

A diverse range of business including restaurants, farms, gourmet or specialty food stores, cooking schools, tour operators, breweries, wineries, historical attractions and many other related companies across the country have capitalized on their regions culturally unique cuisines to attract visitants.

Based on the results of the research, it can be stated that local drinks and regional food are very often integral part of the offer of SMEs operating in gastronomy sector. Local gastronomy and regional productions are perceived as an important part of local heritage and moreover the introduction their offer into the business have a positive impact on the operation of the SMEs in the Czech Republic from the regional perspective. For the future development of food tourism in the Czech regions we recommend to focused on applying more current trends in food tourism and participation in events linked with food and beverages in greater extent. It is important to see events as the catalyst that can help countries and regions achieve their gastronomic objectives. 
Considering saying the opportunities for future research is in widens the interviews to the guest of SMEs (not only domestic visitors but also foreign ones) to find out the impact of regional food and drinks on both, the tourism businesses and the guests.

\section{Acknowledgement}

This paper is based on research project "The influence of food tourism on the development of small and medium-sized enterprises in the Czech Republic", which is supported by the University College of Business in Prague (FRV 1/2015)

\section{Bibliography}

BÈLISLE, F. J. 1983. Tourism and food production in the Cariebbean. In Annals of Tourism Research. vol. 10, no. 3, pp. 497-513.

BREAKWELL, G.M. - HAMMOND, S. - FIFE-SCHAW, C. 2000. Research Methods in Psychology. London : Sage.

CZECH STATISTICAL OFFICE. 2016. Tourism Satellite Account. [online]. Czech Statistical Office. [2016.09.20]. Downloaded from: < https://www.czso.cz/csu/czso/tourism_satellite_account>.

ČUKA, P. - VÁCLAVÍNKOVÁ, K. 2014. Regionální gastronomie v Moravskoslezském kraji jako prostředek pro podporu cestovního ruchu. In Sbornik př̀spěvki - XVII. mezinárodni kolokvium o regionálních vědách. (Hustopeče 18. - 20.6. 2014). Brno: Masarykova univerzita, 2014. ISBN 97880-210-6840-7.

ENTELECA RESEARCH AND CONSULTANCY REPORT. 2000. Tourist's attitudes towards regional and local food. [online]. Prepared for the Ministry of Agriculture, Fisheries and Food and the Countryside Agendy by Enteleca Research and Consultancy Ltd. [2016.09.20]. Available at: <http://www.tourisminsights.info/ONLINEPUB/FARMING\%20AND\%20FO OD/FOOD\%20PDFS/tourist\%20attitutes\%20to\%20local\%20foods.pdf $>$.

EVES, A. - DERVISI, P. 2005. Experiences of the implementation and operation of hazard analysis critical control points in the food service sector. In International Journal of Hospitality Management. vol. 24, pp. 3-19.

GILLHAM, B. 2000. The research interview. London and New York: Continuum. ISBN 0-8264-4797-X.

HALL, C. M. 2004. Small firms and wine and food tourism in New Zealand: Issues of collaboration, clusters and lifestyles. In R. Thomas (Ed.), Small firms in tourism: International perspectives (p. 167 - 181). Oxford: Elsevier.

HALL, C. M. - MITCHELL, R. 2001. Wine and food tourism. In Douglas, N. Douglas, N. - Derrett, R. (Eds), Special interest tourism (p. 307 - 329). Brisbane: John Wiley \& Sons. 
HALL, C. M. - SHARPLES, L. - SMITH, A. 2003. The experience of consumption or the consumption of experiences? Challenges and issues in food tourism. In Hall, C. M., Sharples, E., Mitchell R., Cambourne, B., Macionis, N. (eds.), Food tourism around the world: Development, management and markets (pp. 314-315). Oxford: Butterworth-Heinemann.

HAMARNEH, I. - KOČOVÁ, J. 2016. Cestovni ruch na národní, regionální a mezinárodní úrovni. Praha: Vysoká škola obchodní v Praze, o.p.s. ISBN 97880-86841-58-8.

HAMARNEH, I. - KIRÁL'OVÁ, A. 2016a. Gastronomy and Tourism as a Tool of Regional Development - the Case of Ústí nad Labem Region. In conference proceeding Management 2016. International Business and Management, Domestic Particularities and Emerging Markets in the Light of Research. Slovakia: Prešovská univerzita in Prešov (in press).

HAMARNEH, I. - KIRÁL'OVÁ, A. 2016b. Food Tourism as a Factor of the Regional Tourism Development: Literature Review. In Conference proceedings Topical issues of tourism "Local Heritage and Tourism". Jihlava: College of Polytechnics Jihlava (in press).

HASHIMOTO, A. - TELFER, D. J. 2003. Food tourism in the Niagara region: The development of a ,nouvelle cuisine'.In Hall, C. M., Sharples, E., Mitchell R., Cambourne, B., Macionis, N. (eds.). Food tourism around the world: Development, management and markets (p. 178-191). Oxford: ButterworthHeinemann.

KREJCIE, R. V. - MORGAN, D. W. 1970. Determining sample size for reserch activities. In Educational and Psychological Measurement, 30, p. 607-610.

MACLEOD, N. - ROBERTSON, M. - SMITH, M. 2010. Key Concepts in Tourist Studies. London, Los Angeles, New Delphi, Singapore, Washington D.C.: SAGE Publications Ltd. ISBN 978-1-4129-2104-6.

MERRIAM, S. 2009. Qualitative research: A guide to design and implementation, San Francisco: Jossey-Bass.

MILL, R. C. - MORRISON, A. M. 1998. The tourism system: An introductory text. Dubuque, IA: Kendall/Hunt Publishing Company.

MINISTRY OF AGRICULTURE OF THE CZECH REPUBLIC. Supporting our rural traditions \& development. [online]. Ministry of Agriculture. [2016.09.20]. Available at: http://eagri.cz/public/web/file/214061/publikace_mze_A4_ rozvoj_venkova_ENG_FINAL.pdf.

MINISTRY OF REGIONAL DEVELOPMENT. 2015. Statistiky a analýzy. [online]. Ministry of Regional Development. [2016.09.20]. Available at: <http://www.mmr.cz/cs/Regionalni-politika-a-cestovni-ruch/Cestovni-ruch/Stat istiky-Analyzy $>$.

MISIURA, S. 2006. List of case studies. Heritage Marketing. Abingdon, Oxon: Routledge, pp. $14-16$.

MURPHY, R. F. 1988. Cultural and Social Anthropology, New York: Pearson. 
PATTON, M. Q. 2002. Qualitative Research and Evaluation Methods. Thousand Oaks: Sage.

POON, A. 1993. Tourism, technology and competitive strategies. Wallingford: CAB International.

RICHARDS, G. 2002. Gastronomy: An essential ingredient in tourism production and consumption? In Hjalager, A.M., Richards, G. (eds.). Tourism and gastronomy. London: Routledge.

SELWOOD, J. 2003. The lure of food: Food as an attraction in destination marketing in Manitoba, Canada. In Hall, C. M., Sharples, E., Mitchell R., Cambourne, B., Macionis, N. (eds.). Food tourism around the world: Development, management and markets (pp. 158-177). Oxford: ButterworthHeinemann.

TELFER, D. J. - WALL, G. 1996. Linkages between tourism and food production. In Annals of Tourism Research. vol. 23, no. 3, pp. 635-653.

YEOMAN, I. 2008. Why Food Tourism is Becoming more Important? [online]. Hospitalitynet, Industry News. [2016.09.20]. Downloaded from: <http://www.hospitalitynet.org/news/4037197.html>.

YEOMAN, I. - MCMAHON-BEATTE , U. 2016. The future of food tourism. In Journal of Tourism Futures. vol. 2, no. 1, pp. 95-98.

Ing. Iveta Hamarneh, Ph.D.

Doc. Ing. Alžbeta Királ'ová, Ph.D.

Vysoká škola obchodní v Praze, o. p. s.

Spálená 14, 11000 Praha 1 - Nové Mesto

E-mail: kiralova@vso-praha.eu, hamarneh@vso-praha.eu 